\title{
Bodies and Affects in Market Societies
}

\section{Ed. by Anne Schmidt and Christoph Conrad}

[Körper und Affekte in Marktgesellschaften.]

Bodies and Affects in Market Societies

Edited by

nne Schmidt an

Christoph Conrad

Mohr Siebeck

2016. VIII, 221 Seiten.

ISBN 978-3-16-153592-5

DOI 10.1628/978-3-16-153592-5

eBook PDF $69,00 €$

ISBN 978-3-16-152776-0

Festeinband $69,00 €$
Veröffentlicht auf Englisch.

Wie werden Körper und Affekte in liberalen Marktgesellschaften geformt? Und vice versa: Welche Rolle spielen Affekte und Körper für die Genese, die Stabilisierung und den Wandel von Marktgesellschaften? Diesen Fragen gehen die Autorinnen und Autoren in pointierten Fallstudien mit je eigenem theoretischem Ehrgeiz nach. Das Anliegen des Bandes ist es, neue Forschungsansätze etwa aus der History of Emotions, den Affect Studies oder der Akteur-Netzwerk-Theorie vorzustellen und ihren Nutzen für die Analyse kapitalistischer Gesellschaften zu testen. Die von Soziologen, Ethnologen und Historikern verfassten empirischen Untersuchungen befassen sich mit Entwicklungen in Europa, den USA und Australien vom 19. bis zum 21. Jahrhundert. Themen wie Spekulation, Industrieproduktion, Werbung und Ethik werden in historischen und gegenwartsbezogenen Fallstudien exemplarisch behandelt und dabei Neues zu den Dimensionen Arbeit und Konsum, Klasse und Geschlecht zutage gefördert.

Inhaltsübersicht

Christoph Conrad/Anne Schmidt: Introduction - Thomas Welskopp: Sons of Vulcan. Industrial Relations and Attitudes towards Work among German and American Iron and Steel Workers in the 20th Century - Peter-Paul Bänziger: What Makes People Work: Producing Emotional Attachments to the Workplace in Post-WWII Western German Vocational Schools Alexandra Michel: The Bodily Structuration of Knowledge Work: A Twelve-Year Ethnography of Wall Street Bank Socialization Practices and their Diffusion - Alexander Engel: The Exchange Floor as a Playing Field: Bodies and Affects in Open-Outcry Trading - Fiona Allon: The Wealth Affect: Speculation as Everyday Habitus - Susan J. Matt: From Sin to Economic Stimulant: Envy's Changing Place in American Capitalism - Franck Cochoy: On the Marketization of Curiosity: The Shop Window as a »Captation« Device - Anne Schmidt: From Thrifty Housewives to Shoppers with Needs: On a Capitalist Education Program

Anne Schmidt Born 1967; studied history and German philology; 2004 PhD; since 2008 researcher at the Max-Planck-Institute for Human Development, Center for the History of Emotions.

Christoph Conrad Born 1956; studied history, Islamic studies and philosophy; 1992 PhD; since 2002 professor of modern history at the University of Geneva.

Jetzt bestellen:

https://mohrsiebeck.com/buch/bodies-and-affects-in-market-societies-9783161535925?no_cache=1

order@mohrsiebeck.com

Telefon: +49 (0)7071-923-17

Telefax: +49 (0)7071-51104 